\title{
An experimental assessment of different anaerobic blood culture methods
}

\author{
D. C. SHANSON \\ From the Department of Clinical Microbiology, University College Hospital, London
}

SYNOPSIS Simulated blood cultures were performed to test the ability of various methods to yield growth from small inocula of different strains of bacteroides and anaerobic cocci. For good early growth and reliable isolation of non-sporing anaerobes a Southern Group Brewers thioglycollate method, without Liquoid, appeared to be the best of the methods tested. A glucose cooked meat method also gave good results. Liquoid had no inhibitory effect on bacteroides. Anaerobic cocci were inhibited by Liquoid in some media, particularly thioglycollate, where one out of six strains tested was completely suppressed.

The importance of isolating anaerobes from the blood has become increasingly recognized in recent years. It was decided to test some of the common methods in use in Britain. The most popular methods of anaerobic blood culture were ascertained by means of a questionnaire in 1972. The questionnaire was sent to 88 laboratories of which 60 were public health, 17 teaching hospital, and 11 non-teaching hospital laboratories. Out of 59 laboratories replying, $36 \%$ used no anaerobic method or depended on glucose broth only, $33 \%$ used a cooked meat method, $22 \%$ employed thioglycollate, $7 \%$ used a broth with a metal strip, and $2 \%$ used various other methods. About half of the laboratories that employed an anaerobic method added Liquoid-usually at a concentration of about $0.05 \%$. Only about $25 \%$ of laboratories using anaerobic media prepared their own cooked meat or thioglycollate. Most laboratories obtained both these media from Oxoid, with Southern Group Laboratories (SG) Brewers the next commonest source, and only onelaboratory used BBL products. The volume of meat broth varied between 10 and $100 \mathrm{ml}$, the most popular volume being about $50 \mathrm{ml}$. Thioglycollate was used in volumes of between 15 and $300 \mathrm{ml}$, the larger volumes being favoured by most laboratories, and the average volume was about $90 \mathrm{ml}$. The great majority of laboratories did not use more than one anaerobic bottle routinely. The average volume of blood taken for anaerobic culture from patients was about $4 \mathrm{ml}$.

Experiments were performed to test glucose broth,

Received for publication 23 January 1974. some popular cooked meat and thioglycollate methods, nutrient broth with iron nails added to be transferred to an anaerobic jar after 24 hours, and also the effect of Liquoid. Initial attempts to obtain meaningful Eh measurements of the media proved difficult and instead Clostridia were used in preliminary experiments without blood to compare the ability of the different methods to support anaerobic growth. Subsequently the growth of nonsporing anaerobes was tested in media containing fresh human blood.

\section{Materials and Methods}

\section{BACTERIA}

Bacteroides fragilis NCTC 9343, Sphaerophorus necrophorus NCTC 10575, and Bacteroides melaninogenicus NCTC 9336 were obtained from the National Collection of Type Cultures. B. necrophorus NCTC 7155 was kindly supplied by $\mathrm{Dr}$ J. Collee. The other bacteroides were freshly isolated from routine wound swabs on blood agar, and were presumed to be $B$. fragilis from their antibiotic sensitivity patterns (Sutter and Finegold, 1971) and appearance on blood agar.

Two anaerobic cocci belonged to Hare's groups I and III. They were, respectively, NCTC 9801 (Streptococcus putridus) and NCTC 9803. The other anaerobic cocci tested were obtained from pus or wound swabs on blood agar and failed to grow aerobically in air plus $5-10 \%$ carbon dioxide in four days.

Clostridium welchii NCTC 8237 and Clostridium 
tetani NCTC 9569, a non-spreading type 6 variant, also from Dr Collee, were employed in experiments to test degrees of anaerobiosis.

\section{MEDIA}

\section{Glucose broth}

Southern Group Laboratories (SG), 0.1\%, Oxoid CM $175,0.5 \%, 50$ and $100 \mathrm{ml}$, with $0.1 \%$ agar added for some experiments.

\section{Liquoid broth with iron nail}

Oxoid no. 2 nutrient broth, $10 \mathrm{ml}$, with $0.05 \%$ Liquoid. Two sterile nails were added shortly before each experiment.

\section{Cooked meat broth}

Oxoid CM 82, tablets in 10,20 , and $50 \mathrm{ml}$, with 4, 7 , and $6 \mathrm{~mm}$ depths of meat respectively.

Southern Group Laboratories, about 16 or $80 \mathrm{ml}$, in McCartney or $50 \mathrm{ml}$ bottles, with 22 and $19 \mathrm{~mm}$ meat depths respectively. The $16 \mathrm{ml}$ meat medium contained about $6 \mathrm{ml}$ meat and $10 \mathrm{ml}$ of broth. BBL, $20 \mathrm{ml}$, with $32 \mathrm{~mm}$ depth of meat.

\section{Glucose cooked meat broth}

Southern Group Laboratories, 50 ' $\mathrm{ml}, 0 \cdot 1 \%$ glucose digest broth, with p-amino-benzoic acid added, containing cooked meat to a depth of about $16 \mathrm{~mm}$.

\section{Thioglycollate}

Oxoid Brewers, CM 23, 80, or $130 \mathrm{ml}$.

Southern Group Laboratories Brewers (0586C) $80 \mathrm{ml}$, with a plastic viscap covering each bottle top, to be removed before use.

Oxoid, United States Pharmacopoea (USP) CM $173,80 \mathrm{ml}$. All $80 \mathrm{ml}$ thioglycollates were dispensed in $50 \mathrm{ml}$ bottles. Home-made thioglycollate from another teaching hospital, $30 \mathrm{ml}$, with $0.03 \%$ liquoid.

During storage for up to two months, all the media were in the dark, at room temperature, and with bottle tops screwed tight.

LIQUOID (POLYANETHOL SULPHONATE)

A $5 \%$ Liquoid solution from Roche Ltd was autoclaved and added to nutrient broth for the nail method, and to SG and Oxoid thioglycollates to give a concentration of $0.05 \%$. Other media were supplied from SG with $0.06 \%$ Liquoid already added, including some $16 \mathrm{ml}$ cooked meat and $50 \mathrm{ml}$ glucose meat broths.

FRESH HUMAN BLOOD

Fresh blood was obtained from 26 healthy volunteers not receiving any antibiotics or other drugs.

INOCULATION

The blood was introduced directly after collection into the blood culture bottles and the organisms were added from a calibrated dropping pipette approximately one hour later. Bacteroides melaninogenicus was cultivated on blood agar and emulsified in peptone water, which was then immediately diluted. All the other organisms were cultivated in SG cooked meat broth, usually for 24 to 48 hours. Tenfold dilutions of each organism were made rapidly in peptone water. Preliminary experiments had been performed to determine the most probable dilutions necessary to obtain a small inoculum. A Miles and Misra surface viable count was performed at the same time as the blood culture bottles were inoculated. The actual inoculum was calculated from the results of the count, usually the next day.

\section{THE METHOD FOR EACH BLOOD CULTURE}

EXPERIMENT

Sufficient blood broths were prepared, usually containing $5 \mathrm{ml}$ fresh human blood, although in some experiments less than $5 \mathrm{ml}$ of blood was used. Three donors were normally required and care was taken that blood from each donor was distributed so that possible differences between their blood would not affect the comparison between the methods. Each medium was tested in triplicate. After inoculation the bottles were incubated in the absence of carbon dioxide, except for the iron nail broth which after 24 hours was transferred to an anaerobic jar containing $5 \%$ carbon dioxide. With the latter exception no anaerobic jar was used for the incubation of the blood culture broths. Bottles were subcultured usually after one, two, three, and eight days' incubation onto blood agar which was incubated anaerobically, in jars containing about $5 \%$ carbon dioxide, for up to four days.

\section{OTHER EXPERIMENTS}

Some media were also tested in triplicate with clostridia and non-sporing anaerobes in the absence of blood.

\section{Results}

GROWTH OF CLOSTRIDIA IN BLOOD CULTURE MEDIA WITHOUT BLOOD

Two strains were tested. $\mathrm{Cl}$. welchii represented the common pathogens which are not very strict anaerobes, and a non-spreading $\mathrm{Cl}$.tetani represented the strict anaerobes. As expected, all media to be investigated succeeded with the $\mathrm{Cl}$. welchii (5 viable particles per bottle) after one day, except $50 \mathrm{ml}$ Oxoid glucose broth and $100 \mathrm{ml}$ of the same broth, with or without $0.1 \%$ agar added. Results for $\mathrm{Cl}$. tetani are seen in table I. 


\begin{tabular}{|c|c|c|c|c|}
\hline \multirow[t]{3}{*}{ Medium } & \multicolumn{3}{|c|}{ Day 1} & \multirow{3}{*}{$\begin{array}{l}\text { Day } 5 \\
\text { All Three }\end{array}$} \\
\hline & \multicolumn{3}{|c|}{ Subculture Bottle No. } & \\
\hline & $I$ & 2 & 3 & \\
\hline $\begin{array}{l}\text { Cooked meats } \\
\text { Oxoid } 20 \mathrm{ml} \text { without Liquoid } \\
\text { Oxoid } 50 \mathrm{ml} \text { without Liquoid } \\
\text { BBL } 20 \mathrm{ml} \text { without Liquoid } \\
\text { SG } 16 \mathrm{ml} \text { without Liquoid } \\
\text { SG } 16 \mathrm{ml} \text { with Liquoid } \\
\text { SG } 80 \mathrm{ml} \text { without Liquoid } \\
\text { SG } 50 \mathrm{ml} \text { without Liquoid glucose meat }\end{array}$ & $\begin{array}{l}\mathbf{0} \\
\mathbf{0} \\
\mathbf{G} \\
\mathbf{G} \\
\mathbf{0} \\
\mathbf{G} \\
\mathbf{G}\end{array}$ & $\begin{array}{l}\mathbf{0} \\
\mathbf{0} \\
\mathbf{G} \\
\mathbf{G} \\
\mathbf{0} \\
\mathbf{G} \\
\mathbf{G}\end{array}$ & $\begin{array}{l}0 \\
0 \\
\mathbf{G} \\
\mathbf{G} \\
\mathbf{0} \\
\mathbf{G} \\
\mathbf{G}\end{array}$ & $\begin{array}{l}\mathbf{0} \\
\mathbf{0} \\
\mathbf{G} \\
\mathbf{G} \\
\mathbf{0} \\
\mathbf{G} \\
\mathbf{G}\end{array}$ \\
\hline $\begin{array}{l}\text { Iron nail broth } \\
\text { Oxoid } 10 \mathrm{ml} \text { with Liquoid }\end{array}$ & 0 & $\mathbf{P}$ & $\mathbf{P}$ & $\mathbf{G}$ \\
\hline $\begin{array}{l}\text { Glucose broths } \\
\text { Oxoid } 100 \mathrm{ml} \text { without Liquoid ( } 65 \mathrm{~mm} \text { depth) } \\
\text { Oxoid } 50 \mathrm{ml} \text { without Liquoid }+0.1 \% \text { agar }(32 \mathrm{~mm} \text { depth) } \\
\text { Oxoid } 100 \mathrm{ml} \text { without Liquoid }+0.1 \% \text { agar }(68 \mathrm{~mm} \text { depth) }\end{array}$ & $\begin{array}{l}\mathbf{0} \\
\mathbf{0} \\
\mathbf{0}\end{array}$ & $\begin{array}{l}\mathbf{0} \\
\mathbf{0} \\
\mathbf{0}\end{array}$ & $\begin{array}{l}\mathbf{0} \\
\mathbf{0} \\
\mathbf{0}\end{array}$ & $\begin{array}{l}0 \\
0 \\
G^{2}\end{array}$ \\
\hline $\begin{array}{l}\text { Thioglycollate broths } \\
\text { SG Brewers } 80 \mathrm{ml} \text { without Liquoid } \\
\text { SG Brewers } 80 \mathrm{ml} \text { with Liquoid } \\
\text { Oxoid USP } 80 \mathrm{ml} \text { without Liquoid } \\
\text { Oxoid USP } 80 \mathrm{ml} \text { with Liquoid }\end{array}$ & $\begin{array}{l}\mathbf{G} \\
\mathbf{G} \\
\mathbf{G} \\
\mathbf{P}\end{array}$ & $\begin{array}{l}\mathbf{G} \\
\mathbf{G} \\
\mathbf{G} \\
\mathbf{P}\end{array}$ & $\begin{array}{l}\mathbf{G} \\
\mathbf{G} \\
\mathbf{G} \\
\mathbf{P}\end{array}$ & $\begin{array}{l}\mathbf{G} \\
\mathbf{G} \\
\mathbf{G} \\
\mathbf{G}\end{array}$ \\
\hline
\end{tabular}

Table I Growth of Clostridium tetani in media without blood ${ }^{1}$

${ }^{1} \mathrm{Cl}$. tetani, NCTC 9569, was from a 16-day-old cooked meat culture. The inoculum used was 62 viable particles per bottle.

${ }^{2}$ Large colony variants

$\mathbf{0}=$ No growth; $\mathbf{P}=$ Poor growth (1 to 20 colonies); $\mathbf{G}=$ Good growth

\begin{tabular}{|c|c|c|c|c|c|c|c|c|c|c|c|c|c|c|c|}
\hline \multirow[t]{3}{*}{ Organism } & \multirow{3}{*}{$\begin{array}{l}\begin{array}{l}\text { Inoculum } \\
\text { (No. of }\end{array} \\
\text { Viable } \\
\text { Particles } \\
\text { per Bottle) }\end{array}$} & \multicolumn{7}{|c|}{ Subculture Medium } & & & & & & & \\
\hline & & \multicolumn{7}{|c|}{ At One Day } & \multicolumn{7}{|c|}{ At One Week } \\
\hline & & $\begin{array}{l}\text { SG } \\
\text { Brewers } \\
-L\end{array}$ & $\begin{array}{l}\text { USP } \\
\text { SThio } \\
-L\end{array}$ & $\begin{array}{l}\text { Iron } \\
\text { Nail } \\
+L\end{array}$ & $\begin{array}{l}S G \\
\text { Meat } \\
16 m l \\
-L\end{array}$ & $\begin{array}{l}S G \\
\text { Meat } \\
16 \mathrm{ml} \\
+L\end{array}$ & $\begin{array}{l}\text { Glucose } \\
\text { Meat } \\
+L\end{array}$ & $\begin{array}{l}\text { Oxoid } \\
\text { Meat } \\
50 \mathrm{ml} \\
-L\end{array}$ & $\begin{array}{l}S G \\
\text { Brewers } \\
-L\end{array}$ & $\begin{array}{c}\text { USP } \\
\text { s Thio } \\
-L\end{array}$ & $\begin{array}{l}\text { Iron } \\
\text { Nail } \\
+L\end{array}$ & $\begin{array}{l}S G \\
\text { Meat } \\
16 \mathrm{ml} \\
-L\end{array}$ & $\begin{array}{l}S G \\
\text { Meat } \\
16 \mathrm{ml} \\
+L\end{array}$ & $\begin{array}{l}\text { Glucose } \\
\text { Meat } \\
+L\end{array}$ & $\begin{array}{l}\text { Oxoid } \\
\text { Meat } \\
50 \mathrm{ml} \\
-L\end{array}$ \\
\hline \multicolumn{16}{|l|}{$\begin{array}{l}\text { Bacteroides } \\
\text { B. fragilis }\end{array}$} \\
\hline NCTC 9343 & 23 & + & + & + & - & - & \pm & - & + & - & + & + & + & + & + \\
\hline 27897 & 50 & + & + & + & - & - & \pm & - & + & - & + & + & + & + & + \\
\hline 26191 & 75 & + & + & + & - & - & nt & - & + & - & + & + & + & nt & \pm \\
\hline \multicolumn{16}{|l|}{$\begin{array}{l}21694 \\
\text { B. necrophorus }\end{array}$} \\
\hline $\begin{array}{l}\text { B. necrophorus } \\
\text { NCTC } 7155 \\
\text { S.necrophorus }\end{array}$ & 70 & + & + & + & - & - & \pm & - & + & + & + & - & - & + & \pm \\
\hline $\begin{array}{l}\text { NCTC } 10575 \\
\text { B. melaninogenicus }\end{array}$ & 44 & - & - & - & - & - & - & - & + & + & $-* 3$ & + & + & + & - \\
\hline NCTC 9336 & 70 & - & $-* 2$ & - & - & - & - & - & + & - & $-* 3$ & - & - & + & - \\
\hline \multicolumn{14}{|l|}{ Anaerobic Cocci } & & \\
\hline $\begin{array}{l}\text { NCTC } 9801 \\
38890\end{array}$ & $\begin{array}{l}26 \\
44\end{array}$ & $\bar{t}$ & $\bar{t}$ & $\begin{array}{l}- \\
-\end{array}$ & \pm & - & $\bar{t}$ & - & + & + & $\begin{array}{l}+ \\
+\end{array}$ & + & + & $\begin{array}{l}+ \\
+\end{array}$ & \pm \\
\hline Otto & 100 & $\begin{array}{l}I \\
+\end{array}$ & $-* 2$ & - & + & + & $\begin{array}{l}I \\
\text { nt }\end{array}$ & + & + & - & + & + & + & nt & + \\
\hline 17062 & 70 & $\pm^{* 1}$ & + & - & + & - & \pm & - & - & - & + & + & + & + & - \\
\hline NCTC 9803 & 40 & + & nt & - & + & - & $\mp$ & - & + & nt & + & + & + & + & \pm \\
\hline & 12 & 11 & 12 & 12 & 12 & 9 & 12 & 12 & 11 & 12 & 12 & 12 & 9 & 12 \\
\hline \multicolumn{2}{|c|}{$\begin{array}{l}\text { Total no. strains tested } \\
\text { Total no. strains growing as } \pm \text { or }+\end{array}$} & 9 & 7 & 5 & 4 & 1 & 6 & 1 & 11 & 4 & 10 & 9 & 10 & 9 & 7 \\
\hline
\end{tabular}

Table II Anaerobic growth in blood cultures after incubation for one day and one week
$L=$ Liquoid
$* 1=+$ at 48 hours $\quad$ nt $=$ not tested
$* 2=+$ at 72 hours
$* 2=+$ at 72 hours
All three bottles positive $=+$
Two out of three bottles positive $= \pm$

$5.0 \mathrm{ml}$ fresh human blood added to each bottle

Nil or one out of three bottles positive = -

\section{INVESTIGATION OF METHODS WITH BLOOD}

Tables II, III, and IV summarize the results for most of the methods tested, with the addition of blood.

Southern Group Laboratories Brewers, without Liquoid, appeared to give the best overall isolation of 


\begin{tabular}{|c|c|c|c|c|c|c|c|c|c|c|c|c|c|c|c|c|}
\hline & \multicolumn{10}{|c|}{ Bacteroides } & \multicolumn{6}{|c|}{ Anaerobic Cocci } \\
\hline & \multicolumn{2}{|c|}{$\begin{array}{l}\text { B. fragilis } \\
\text { NCTC } 9343\end{array}$} & \multicolumn{2}{|c|}{$\begin{array}{l}\text { B. fragilis } \\
\text { Routine } \\
21694\end{array}$} & \multicolumn{2}{|c|}{$\begin{array}{l}\text { B. necro- } \\
\text { phorus } \\
\text { NCTC } 7155\end{array}$} & \multicolumn{2}{|c|}{$\begin{array}{l}\text { B. melanino- } \\
\text { genicus } \\
\text { NCTC } 9336\end{array}$} & \multicolumn{2}{|c|}{$\begin{array}{l}\text { S. necrophorus } \\
\text { NCTC } 105755\end{array}$} & \multicolumn{2}{|c|}{$\begin{array}{l}\text { NCTC } \\
9803\end{array}$} & \multicolumn{2}{|c|}{$c_{1}$, Routine } & \multicolumn{2}{|c|}{$\begin{array}{l}\text { NCTC } \\
9801\end{array}$} \\
\hline $\begin{array}{l}\text { Inoculum (viable particles } \\
\text { per bottle) }\end{array}$ & & 14 & & 13 & & 8 & & 10 & & 16 & & 36 & & 48 & & 62 \\
\hline $\begin{array}{l}\text { No. of days incubation } \\
\text { SG cooked meat, } 80 \mathrm{ml} \\
\text { SG Brewers, } 80 \mathrm{ml} \\
\text { Oxoid Brewers, } 80 \mathrm{ml} \\
\text { Oxoid Brewers, } 130 \mathrm{ml}\end{array}$ & $\begin{array}{l}2 \\
+ \\
++ \\
+t \\
+t\end{array}$ & $\begin{array}{l}8 \\
+\cdots \\
++ \\
- \\
-\end{array}$ & $\begin{array}{l}2 \\
- \\
\cdots \\
\cdots\end{array}$ & $\begin{array}{l}8 \\
+ \\
- \\
- \\
-\end{array}$ & $\begin{array}{l}1 \\
- \\
++ \\
++ \\
++\end{array}$ & $\begin{array}{l}8 \\
\pm \\
++ \\
++ \\
++\end{array}$ & $\begin{array}{l}4 \\
- \\
++ \\
++ \\
+\end{array}$ & $\begin{array}{l}8 \\
\pm \\
++ \\
\pm \\
\pm\end{array}$ & $\begin{array}{l}4 \\
++ \\
++ \\
- \\
-\end{array}$ & $\begin{array}{l}8 \\
+ \\
++ \\
+ \\
-\end{array}$ & $\begin{array}{l}2 \\
++ \\
++ \\
++ \\
++\end{array}$ & $\begin{array}{l}8 \\
++ \\
++ \\
- \\
-\end{array}$ & $\begin{array}{l}4 \\
++ \\
++ \\
++ \\
++\end{array}$ & $\begin{array}{l}8 \\
++ \\
++ \\
++ \\
++\end{array}$ & $\begin{array}{l}2 \\
+ \\
++ \\
++ \\
++\end{array}$ & $\begin{array}{l}8 \\
++ \\
++ \\
++ \\
++\end{array}$ \\
\hline
\end{tabular}

Table III A comparison of thioglycollate and cooked meat blood cultures without Liquoid ${ }^{1}$

${ }^{1}$ All bottles contained $5.0 \mathrm{ml}$ fresh human blood immediately before inoculation

All three bottles positive $=++$, two out of three bottles positive $=+$, one out of three bottles positive $= \pm$, none out of three bottles positive $=-$.

superior to the other thioglycollate media in that it gave much more reliable growth at one week.

Although USP thioglycollate often failed because it killed anaerobes one week after growth had started, it provided the most rapid growth of the B. melaninogenicus strain. In three experiments, where inocula ranged from 8 to 70 viable particles per bottle, $B$. melaninogenicus always grew at three days in USP thioglycollate compared with four days for SG Brewers.

The one home-made thioglycollate medium tested yielded growth of $\boldsymbol{B}$. fragilis strains only after three days, in six experiments using inocula of $4,27,30$, 44,75 , and 150 viable particles per bottle. This contrasted with the commercial thioglycollates which normally yielded growth of $B$. fragilis reliably after one day. In the home-made medium two anaerobic cocci strains also failed to grow, added as inocula of 10 and 32 viable particles per bottle, by one week.

In the absence of liquoid, $130 \mathrm{ml}$ thioglycollate broth gave no apparent advantage over $80 \mathrm{ml}$, and $80 \mathrm{ml}$ thioglycollate broth gave much better results than $80 \mathrm{ml} \mathrm{SG}$ cooked meat (see table III).

\section{Cooked meat methods}

Only one meat method supported the growth of all the different species of anaerobe tested, namely, SG glucose digest cooked meat. No organism was inhibited in the glucose meat one week after growth had started. The growth of Bacteroides fragilis, necrophorus, and melaninogenicus was quicker and more reliable in the glucose meat method than in the non-glucose cooked meats. The smallest inoculum of $\boldsymbol{B}$. fragilis tested in the glucose meat was 4 viable particles per bottle. On this occasion a routine strain, 3027, was used, and growth occurred in all three bottles after three days.

Anaerobic cocci usually grew well in non-glucose cooked meats from SG in large and small volumes after three days. In contrast to bacteroides, glucose

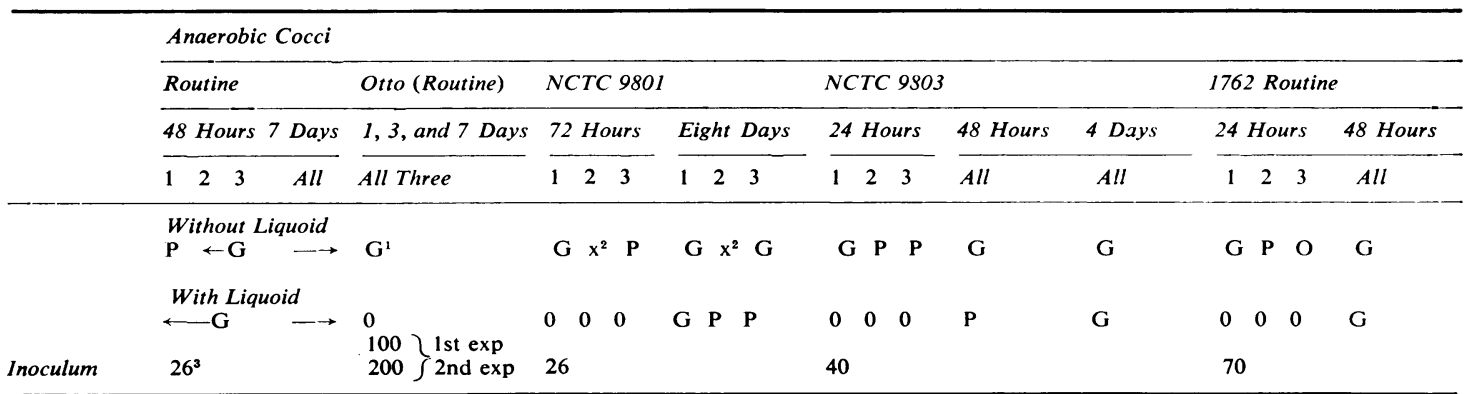

Table IV The effects of Liquoid on five anaerobic cocci in $80 \mathrm{ml}$ Southern Group Brewers Laboratories thioglycollate

${ }^{1}$ For both experiments, ${ }^{2} x=$ contamination ${ }^{3}$ No. of viable particles per bottle.

All bottles had $5.0 \mathrm{ml}$ fresh human blood added immediately before inoculation

On subculture: $\mathbf{0}=$ no growth, $\mathbf{P}=$ poor growth (1 to 20 colonies), $\mathbf{G}=$ good growth 
cooked meat gave no advantage over these cooked meats.

Small volumes of cooked meat from sources other than SG were tested on only a few occasions after one week's incubation. One routine strain of $B$. fragilis ( 9 viable particles per bottle) grew reliably in $20 \mathrm{ml}$ BBL cooked meat. Oxoid cooked meat Liquoid broth, $10 \mathrm{ml}$, completely failed to support the growth of a $B$. fragilis strain $(3027,30$ viable particles per bottle) and yielded growth of an anaerobic coccus (strain 38890) added as 10 viable particles per bottle, in only one out of three bottles. In contrast, SG $16 \mathrm{ml}$ Liquoid cooked meat, which was tested in parallel with the Oxoid meat, supported the growth of both these anaerobes in all bottles.

Only about $60 \%$ of the anaerobes grew reliably from small inocula after one week in Oxoid cooked meat in $50 \mathrm{ml}$ volume, compared with about $90 \%$ from $16 \mathrm{ml} \mathrm{SG}$ cooked meat (see table II).

\section{Iron nail Liquoid nutrient broth}

The iron nail broth method facilitated the rapid and reliable isolation of $B$. fragilis and the $B$. necrophorus strain, similar to SG Brewers, and much better than the non-glucose cooked meats tested. However, two bacteroides, $S$. necrophorus and $B$. melaninogenicus, failed to grow in the iron nail broth. Anaerobic cocci were reliably isolated after one week, but growth in the first two or three days was slower than in parallel non-Liquoid SG Brewers.

\section{Glucose broth}

Three of the four $B$. fragilis strains, the $B$. necrophorus strain, and both strains of anaerobic cocci tested failed to grow in $50 \mathrm{ml}$ glucose Liquoid broth. The inocula used ranged from 10 to 70 viable particles per bottle. In $100 \mathrm{ml} 0.5 \%$ glucose broth with $0 \cdot 10 \%$ agar, the $S$. necrophorus strain (44 viable particles per bottle) grew poorly in one bottle and not at all in the two other bottles by one week. The B. melaninogenicus strain (70 viable particles per bottle) completely failed to grow in the latter medium by eight days.

STATISTICAL DIFFERENCES BETWEEN THE BLOOD CULTURE METHODS

The different methods were compared by ranking them first according to rapidity of growth, and second, amount of growth, performing statistical analyses by applying Friedman's test, or where only two methods were involved, the Sign test.

For anaerobic Gram-negative bacilli the methods could be divided into two groups. The first group consisted of SG Brewers and USP thioglycollate, both with and without Liquoid, iron nail broth, and glucose cooked meat. The second group included
SG cooked meat, $16 \mathrm{ml}$, with and without Liquoid and Oxoid cooked meat, $50 \mathrm{ml}$. The methods in the first group were significantly better than the methods in the second group for the isolation of the organisms after 24 hours ( $\mathrm{p}<0.05)$.

In the absence of Liquoid, SG Brewers was significantly better than $80 \mathrm{ml} \mathrm{SG}$ cooked meat broth and $130 \mathrm{ml}$ Oxoid Brewers, for good growth of anaerobic Gram-negative bacilli in the first four days $(P<0.05)$, but it was not significantly better than $80 \mathrm{ml}$ Oxoid Brewers. As expected the SG Brewers was also highly significantly better than glucose broth methods $(\mathrm{P}<0.01)$.

For the growth of anaerobic cocci in the first three days, the methods in a group consisting of SG Brewers without Liquoid, $16 \mathrm{ml} \mathrm{SG}$ cooked meat without Liquoid, and glucose cooked meat with Liquoid, were significantly better than methods in another group comprising iron nail Liquoid nutrient broth, both SG Brewers and USP thioglycollate when Liquoid was added, and $50 \mathrm{ml}$ Oxoid cooked meat without Liquoid $(P<0.05)$. When SG cooked meat, $16 \mathrm{ml}$, with or without Liquoid was compared with $50 \mathrm{ml}$ Oxoid cooked meat without Liquoid, the SG meat was highly significantly better for the early growth of anaerobic cocci $(P<0.01)$. No statistical difference could be shown for the early growth of cocci between SG Brewers and small or large volumes of SG cooked meat when Liquoid was omitted.

EFFECT OF LIQUOID IN THIOGLYCOLLATE AND COOKED MEAT BLOOD CULTURES

The number of bacteroides isolated in the first few days was not altered significantly by adding Liquoid to thioglycollate media, but the growth was more abundant than when Liquoid was omitted on 17 out of 46 occasions, with no difference on 23 occasions. This gave a significant result of more abundant growth with Liquoid $(P<0.05)$. Anaerobic cocci, however, were greatly inhibited by Liquoid in thioglycollate media. Table IV shows the effect of Liquoid on five anaerobic cocci in $80 \mathrm{ml} \mathrm{SG}$ Brewers, with the total suppression of one anaerobic coccus by Liquoid. The latter coccus was also suppressed in $80 \mathrm{ml}$ Oxoid Brewers and USP thioglycollate, only when Liquoid was present. For the early growth of anaerobic cocci, SG Brewers without Liquoid was highly significantly better than when Liquoid was added $(P<0.01)$.

In media without blood, Liquoid had no inhibitory effect on $\mathrm{Cl}$. welchii, but $\mathrm{Cl}$. tetani was greatly inhibited in USP thioglycollate and suppressed in SG $16 \mathrm{ml}$ cooked meat (see table I). When Liquoid was present 3 anaerobic cocci and the $S$. necrophorus strain were suppressed by Liquoid in SG $16 \mathrm{ml}$ cooked 


\begin{tabular}{|c|c|c|c|c|c|c|c|c|c|}
\hline \multirow[t]{3}{*}{ Organism } & \multirow{3}{*}{$\begin{array}{l}\text { Inoculum } \\
\text { (number of viable } \\
\text { particles per bottle) }\end{array}$} & \multicolumn{4}{|c|}{ At One Day } & \multicolumn{4}{|c|}{ At One Week } \\
\hline & & \multicolumn{2}{|c|}{ With Blood } & \multicolumn{2}{|c|}{ Without Blood } & \multicolumn{2}{|c|}{ With Blood } & \multicolumn{2}{|c|}{ Without Blood } \\
\hline & & $\begin{array}{l}\text { Without } \\
\text { Liquoid }\end{array}$ & $\begin{array}{l}\text { With } \\
\text { Liquoid }\end{array}$ & $\begin{array}{l}\text { Without } \\
\text { Liquoid }\end{array}$ & $\begin{array}{l}\text { With } \\
\text { Liquoid }\end{array}$ & $\begin{array}{l}\text { Without } \\
\text { Liquoid }\end{array}$ & $\begin{array}{l}\text { With } \\
\text { Liquoid }\end{array}$ & $\begin{array}{l}\text { Without } \\
\text { Liquoid }\end{array}$ & $\begin{array}{l}\text { With } \\
\text { Liquoid }\end{array}$ \\
\hline \multicolumn{10}{|l|}{$\begin{array}{l}\text { Bacteroides } \\
\text { B. fragilis }\end{array}$} \\
\hline NCTC 9343 & 23 & - & - & + & \pm & + & + & + & + \\
\hline 27897 & 50 & - & - & + & + & + & + & + & + \\
\hline 26191 & 75 & - & - & + & + & + & + & + & + \\
\hline 21694 & 20 & - & - & + & \pm & - & + & + & + \\
\hline \multicolumn{10}{|l|}{ B. necrophorus } \\
\hline NCTC 7155 & 70 & - & - & + & + & - & - & + & + \\
\hline $\begin{array}{l}\text { S. necrophorus } \\
\text { NCTC } 10575\end{array}$ & 44 & - & - & & - & + & + & + & - \\
\hline \multicolumn{10}{|l|}{ B. melaninogenicus } \\
\hline NCTC 9336 & 70 & - & - & - & - & - & - & - & - \\
\hline \multicolumn{10}{|l|}{ Anaerobic Cocci } \\
\hline NCTC 9801 & 26 & \pm & - & + & - & + & + & + & - \\
\hline 38890 & 44 & - & - & + & - & + & + & + & - \\
\hline Otto & 100 & + & + & + & + & + & + & + & + \\
\hline 17062 & 70 & + & - & \pm & - & + & + & + & - \\
\hline NCTC 9803 & 40 & + & - & - & - & + & + & + & + \\
\hline \multirow{2}{*}{\multicolumn{2}{|c|}{$\begin{array}{l}\text { Total no. of strains tested } \\
\text { Total no. of strains growing as } \pm \text { or }+\end{array}$}} & 12 & 12 & 12 & 12 & 12 & 12 & 12 & 12 \\
\hline & & 4 & 1 & 10 & 6 & 9 & 10 & 11 & 7 \\
\hline
\end{tabular}

Table V Anaerobic growth in SG $16 \mathrm{ml}$ cooked meat with and without blood or Liquoid

All bottles with blood had $5.0 \mathrm{ml}$ fresh human blood added

All three bottles positive $=+$, two out of three bottles positive $= \pm$, none or one out of three bottles positive $=-$

meat without blood. Nonetheless, these organisms were reliably isolated at one week when $5.0 \mathrm{ml}$ of blood had been added to the medium (see table $V$ ) although during the first few days Liquoid was still inhibitory.

EFFECT OF ADDING DIFFERENT BLOOD VOLUMES TO MEDIA

For the SG $16 \mathrm{ml}$ cooked meat, with and without Liquoid, $5.0 \mathrm{ml}$ blood was clearly inhibitory after 24 hours, even in the meat with Liquoid, and at one week $B$. necrophorus remained suppressed (table $V$ ). The same meat medium, with Liquoid, was also tested with $1.0 \mathrm{ml}$ blood, using small inocula of three $B$. fragilis strains and two strains of anaerobic cocci. All five organisms grew well after only 24 hours, indicating that $1.0 \mathrm{ml}$, unlike $5.0 \mathrm{ml}$, of fresh human blood had no inhibitory effect in this medium.

\section{Discussion}

When bacteria in the bloodstream are few, the larger the volume of blood cultured the greater the chance of isolation. As most laboratories use only one anaerobic bottle routinely it would be preferable to aim at culturing $5.0 \mathrm{ml}$ of blood rather than smaller volumes. More than one anaerobic bottle could be used if anaerobic bacteraemia was clinically suspected and in 'blood culture negative' endocarditis.

The culture of $5.0 \mathrm{ml}$ of blood for anaerobes presents difficulties. Clotting must be prevented, the cidal power of the blood must be neutralized, either with Liquoid or by dilution, and anaerobiosis must be maintained. A broth capable of isolating Cl. welchii is sometimes assumed to be satisfactory for anaerobic blood cultures. In civilian life, however, non-sporing anaerobes infect much more commonly than Clostridia (Stokes, 1958) and most often are far more fastidious than $\mathrm{Cl}$. welchii. $\mathrm{Cl}$. tetani is a good indicator of satisfactory anaerobiosis, but a broth plus blood should also be able to yield a good growth of most non-sporing anaerobes from small inocula within two or three days, if it is to be employed for blood culture. The artificial blood culture experiments indicated three media that were the most successful in meeting all these requirements. They were SG Brewers, $80 \mathrm{ml}$, without Liquoid, Oxoid USP thioglycollate, $80 \mathrm{ml}$ without Liquoid, and $50 \mathrm{ml}$ glucose cooked meat Liquoid digest broth.

However another requirement is that the organisms should remain viable for several days after the start of growth since many laboratories perform subcultures routinely only once or twice a week. The USP thioglycollate and Oxoid Brewers failed this requirement. With regard to certain aerobes the fall in $\mathrm{pH}$ produced from the fermentation of $0.25 \%$ glucose in tryptone soya broth was shown to be associated with a rapidly lethal effect (Waterworth, 1972). The glucose concentration in SG Brewers, $0.25 \%$, is half that in Oxoid Brewers and USP thioglycollate. In addition the SG Brewers is more 
alkaline initially, $\mathrm{pH} 7 \cdot 5$, than the other thioglycollate media. These two factors possibly explain the lesser inhibition of anaerobes in the SG Brewers compared with that of the other thioglycollates.

The SG Brewers was superior to the glucose cooked meat digest broth as it more often yielded growth of some anaerobic Gram-negative bacilli after overnight incubation.

Consistently good results were obtained using SG Brewers without Liquoid in that isolations were achieved from all three bottles of simulated blood cultures for each of the 13 non-sporing anaerobes tested. All except one coccus survived for at least one week in the culture.

Home-made thioglycollate should not be employed unless batches tested with small inocula are shown to be satisfactory.

Liquoid, at a final concentration of 0.03 to $0.05 \%$, does not inhibit aerobes in blood broth (Von Haebler and Miles, 1938). Anaerobic cocci have been reported to be inhibited by Liquoid in artificial blood cultures using liver broth (Hoare, 1938), but no reports could be found of similar inhibition in blood culture media in current use in Britain. In SG Brewers plus blood, $0.05 \%$ Liquoid was seen here to be inhibitory to four out of six anaerobic cocci strains tested and totally suppressed one strain. Similar results were seen in the other thioglycollate media tested, although an individual strain was occasionally inhibited in one type of thioglycollate and not in others. The addition of blood appeared to neutralize the inhibitory effect of Liquoid on anaerobic cocci in $16 \mathrm{ml} \mathrm{SG}$ cooked meat. This could simply be due to the dilution of Liquoid.

Fresh human blood, at a concentration of approximately $30 \%$, inhibited bacteroides in $16 \mathrm{ml} \mathrm{SG}$ cooked meat both with and without Liquoid. Perhaps the capacity of Liquoid to neutralize the antibacterial effect of fresh blood was overcome by such a high concentration of blood in this medium.

As well as avoiding the problem of inhibition of anaerobic cocci by Liquoid the dilution method has the advantage of also diluting any antibacterial drugs present. The work of Roome and Tozer (1968) for aerobes suggests that a 1 in 30 and preferably 1 in 50 dilution of blood is necessary. However, the above experimental results for anaerobes indicate that a 1 in 17 dilution with thioglycollate is satisfactory.

The poor results with Oxoid cooked meat, $50 \mathrm{ml}$, and even worse results with glucose broth methods suggest that these media should not be used for the isolation of small numbers of strict anaerobes.

An experimental approach to finding the best blood culture methods has severe limitations. Bacteria direct from clinical specimens may be more difficult to isolate than those subcultured in the laboratory. A clinical trial of different methods is necessary but difficult to organize since there are relatively few patients with anaerobic bacteraemia. Such a trial might be possible by studying symptomless anaerobic bacteraemia after dental manipulation or during surgery on the large intestine.

I am grateful to Dr Joan Stokes for help and encouragement in the preparation of this paper.

I am grateful for advice received from $\mathrm{Mr} \mathrm{L}$. Freedman of the MRC Statistics Unit and for useful discussions with Dr A. F. Mohun. My thanks are also due to all the Clinical Pathology Laboratory staff of the Whittington Hospital, particularly for their cooperation as blood donors.

\section{References}

Hoare, E. D. (1938). Suitability of 'liquoid' for use in blood culture media, with particular reference to anaerobic Streptococci. $J$. Path. Bact., 48, 573-577.

Roome, A. P. C. H., and Tozer, R. A. (1968). Effect of dilution on the growth of bacteria from blood cultures. J. clin. Path., 21, 719-721.

Stokes, E. J. (1958). Anaerobes in routine diagnostic culture. Lancet, $1,668-670$.

Sutter, V. L., and Finegold, S. M. (1971). Antibiotic disc susceptibility tests for rapid presumptive identification of Gramnegative anaerobic bacilli. Appl. Microbiol., 21, 13-20.

Von Haebler, T., and Miles, A. A. (1938). The action of sulphonate ('Liquoid') on sodium polyanethol blood cultures. J. Path. Bact. 46, 245-252.

Waterworth, P. M. (1972). The lethal effect of tryptone soya broth. $J$. clin. Path., 25, 227-228. 